Relations industrielles

Industrial Relations

\title{
Eaton, Adrienne A. and Jeffrey H. Keefe, editors, Employment Dispute Resolution and Worker Rights
}

\section{Allen Ponak}

Volume 55, numéro 3, 2000

URI : https://id.erudit.org/iderudit/051334ar

DOI : https://doi.org/10.7202/051334ar

Aller au sommaire du numéro

Éditeur(s)

Département des relations industrielles de l'Université Laval

ISSN

0034-379X (imprimé)

1703-8138 (numérique)

Découvrir la revue

Citer ce compte rendu

Ponak, A. (2000). Compte rendu de [Eaton, Adrienne A. and Jeffrey H. Keefe, editors, Employment Dispute Resolution and Worker Rights]. Relations industrielles / Industrial Relations, 55(3), 534-537.

https://doi.org/10.7202/051334ar

Tous droits réservés @ C Département des relations industrielles de l'Université Laval, 2000
Ce document est protégé par la loi sur le droit d'auteur. L’utilisation des services d'Érudit (y compris la reproduction) est assujettie à sa politique d'utilisation que vous pouvez consulter en ligne.

https://apropos.erudit.org/fr/usagers/politique-dutilisation/ 
qui pourraient dévaluer les réserves des caisses d'assurance-chômage. Quoi qu'il en soit, ce volume demeure une référence de premier choix sur une question très pointue, mais articulée à de nombreux débats actuels (opposition capitalisation-répartition, liens entre les politiques sociales et la financiarisation de l'économie, modalités de renforcement de la protection assurancielle, etc.).

Il faut aussi souligner que les deux ouvrages sont complémentaires, $\mathrm{W}$. Vroman étant également l'un des contributeurs de l'ouvrage collectif. À ce titre, cette étude actualise des éléments traités dans le volume précédent. D'ailleurs, on aura noté que, dans les deux cas, l'éditeur est le W.E. Upjohn Institute for Employ- ment Research, organisme sans but lucratif, dont les recherches sont, depuis 1932, consacrées à l'étude des problèmes liés à l'emploi et à la diffusion de propositions visant à les résoudre.

En somme, le grand intérêt de ces ouvrages, pour quiconque s'intéresse à la sécurité du revenu et aux politiques sociales, sera, par delà les éléments d'information ou d'analyse ciblée, de susciter des interrogations sur la variété des arrangements possibles par lesquels est assurée la protection collective contre le risque social du chômage.

\section{Sylvie MoreL Université Laval}

\section{Employment Dispute Resolution and Worker Rights}

edited by Adrienne A. EATON and Jeffrey H. KEEFE, Champaign, Illinois: IRRA, 1999, 303 p., ISBN 0-913447-77-3.

This book is the latest in a series of excellent research volumes commissioned and published by the Industrial Relations Research Association. Like its predecessors, the book provides a comprehensive summary of extant research on its chosen subject, in this case employment dispute resolution, identifies the strengths and weaknesses of the research, and raises many worthwhile questions for future research. It is an indispensable addition to anyone contemplating teaching or research in this area.

The volume contains eight chapters as well as an introductory chapter by the editors. In looking at the list of chapters, two important points can be made. First, there is no comparative chapter, which is unfortunate because some of the issues which are repeatedly raised, particularly in the nonunion arena, are ones where the experience of other countries, for example with respect to European labour courts, is especially instructive. More so than previous research volumes, this is really a book about United States. Any reference to Canada is made in passing as part of the general discussion of research findings. Second, three out of eight chapters are devoted almost exclusively to developments in the nonunion sector, and many of the other chapters pay some attention to nonunion workplaces. An industrial relations volume on employment dispute resolution written only ten years ago would have been very unlikely to have devoted anywhere near the amount of space to this subject. Although Canadians might be unaware of the explosive growth in nonunion arbitration in the U.S., the decision to highlight nonunion dispute resolution is well founded and a particular strength of the volume.

The introductory chapter by the book's editors, Professors Eaton and Keefe, describes the volume and sets out it themes. A brief, but informative, chapter by chapter summary is provided. The editors characterize the grievance arbitration system in the unionized sector as stable and enduring, a depiction which is borne out in the various chapters. They then ask whether the muchheralded "transformation" of industrial 
relations has translated into a transformation of traditional dispute resolution mechanisms at the workplace. My own reading of the chapters is that the answer to this question is "no": unionized parties are fairly content with current grievance and arbitration procedures. The editors are more charitable, agreeing that while there is not much evidence of change in unionized dispute procedures, the lack of evidence can partly be attributed to the lack of research looking for change. Readers can make up their own minds, but one only has to look at the chapter on grievance mediation, a process that wins almost universal approval but is hardly used, to see that there is relatively little interest in changing a system that has apparently served its participants well enough.

Professors Eaton and Keefe contrast the stability of the union sector to the developments in the nonunion sector, describing the latter as the "Wild West" of dispute resolution. It is rapidly expanding but little researched outside the legal field. The editors provide a number of astute observations on nonunion dispute resolution, in particular as to who is actually using it. In their view, it is supervisory, administrative, and middle management employees who have the most to gain or lose by the spread of nonunion dispute procedures. Cast in this light, nonunion arbitration is not a threat to traditional union membership but an opportunity, a point made in Chapter 3.

Following the introductory chapter, Chapters 2, 3, and 4 are devoted to developments in the nonunion sector. To place these chapters in context (and at the risk of over simplification), a 1991 U.S. Supreme Court decision, Gilmerv. Johnson/Interstate Lane, made it legal for employers to require nonunion employees, as a condition of employment, to agree to arbitrate any employment dispute, including statutory claims. After Gilmer, employees signing such agreements (i.e. employees who wanted to get or keep a job), were unable to go to court to pursue their claims, for example, against age discrimination or sexual harassment. Moreover, while employees could be required to arbitrate their disputes and give up their legal rights, there were no guarantees that such arbitration procedures would be fair - and indeed most were not. Mandatory employer promulgated arbitration procedures frequently lack the most basic elements of due process, set arbitrarily low limits on damages, allow employers to choose the arbitrator, and preclude employee representation.

Chapter 2, written by Katherine Stone, is an informative and scathing analysis of the development of the law leading up to Gilmer. Professor Stone characterizes mandatory arbitration procedures as "a vehicle for disenfranchisement and oppression" (p. 51) and as "the yellow dog contract of the 1990s" (p. 34). In her view, the principle motivation of employers is the avoidance of "exploding employment litigation liability" and has little to do with union avoidance or a desire to practice progressive human resources. Chapter 3, by Arnold Zack, an experienced arbitrator, shares similar concerns, but focuses on the development and spread of a Due Process Protocol designed to overcome some of the worst abuses of mandatory nonunion arbitration. The Protocol, set out at the end of the chapter, is a voluntary standard that attempts to ensure basic procedural fairness, including mutual selection of arbitrators, representation rights, and access to information. The Protocol was adopted in 1995 and signed by, among other organizations, the American Bar Association, the National Academy of Arbitrators, the Federal Mediation and Conciliation Service, SPIDR, and the American Civil Liberties Union. The National Academy of Arbitrators, for example, encourages its members to decline appointments in cases where the Protocol standards are not met. Chapter 4 , by Lisa Bingham 
and Denise Chachere, then looks at the state of empirical research on nonunion dispute resolution, including mediation, arbitration and ombuds programs, and concludes that there are a huge number of unanswered questions. The authors list important topics for research such as distributive and procedural justice issues, decision standards, and characteristics of neutrals. These are issues that have been extensively researched in unionized settings, but not yet in nonunion workplaces. Professors Bingham and Chachere note that many nonunion procedures are guarded by confidentiality agreements, making research very difficult.

The book then turns to the more familiar unionized terrain beginning with an outstanding review of grievance procedure and arbitration research by David Lewin in Chapter 5. The volume's longest chapter begins by identifying and critiquing eight different theoretical frameworks used to inform grievance arbitration research, including systems theory, exit, voice, and loyalty, and organizational punishment - industrial discipline. Professor Lewin argues that grievance arbitration research is less atheoretical than commonly believed. Next, the voluminous empirical research is reviewed on four dimensions: (1) grievance initiation; (2) speed and level of settlement; (3) perceived effectiveness; and (4) decisions/outcomes. In a tour de force, the author creates a table that specifies the main studies, hypotheses, methodologies, and findings in each of these dimensions. In suggesting new research areas, the point is made repeatedly that much of the available research focuses on the "tip of the iceberg" because it neglects complaints resolved informally before becoming identifiable grievances and the many situations where employees choose not to grieve potentially grievable contractual violations. In the latter instance, Professor Lewin notes that his own research has demonstrated that retaliatory behaviour against grievors (and their supervisors) is common, exercising a dampening effect on grievance initiation. The chapter concludes with a good summary of the contributions and failures of the traditional grievance procedure and arbitration system.

The next chapter, by Peter Feuille, focuses on grievance mediation, a process long advocated for curing some of the defects of traditional grievance arbitration, such as cost, adversarialism, and delay. The chapter concentrates on formal mediation systems just prior to arbitration, mentioning only in passing an increasingly common phenomenon in Canada, mediation by the arbitrator at the actual arbitration hearing. Professor Feuille discusses various studies that repeatedly show that grievance mediation is an effective dispute resolution procedure and then explores why, given its success, it is rarely adopted. An intriguing part of the analysis is a discussion why employers would resist mediation; the author suggests that management enjoys certain inherent advantages in traditional arbitration, such as superior resources, that are lost in mediation.

In Chapter 7, Michelle Kaminski looks at the grievance procedure in combination with new forms of work organization, noting that while there is a huge amount of research on each of these two subjects, the research rarely intersects. A framework is developed for classifying dispute resolution procedures as either reactive (traditional grievance procedures) or proactive (direct forms of employee involvement). Noting that employee involvement frequently is associated with a decline in grievances, Professor Kaminski asks whether this is due to fewer problems or simply more pressure to conform. Answering this question is clearly an important area for further research. In fact, the author develops ten research propositions for examining the territory where grievance procedures and new forms of work 
organization collide, setting out an interesting and important research agenda for the future.

The final two chapters in the volume look at dispute resolution in the public sector and in construction. The former, by Jill Kriesky, highlights a general lack of research assessing grievance procedures in the public sector and, in particular, the way in which dispute procedures under collective agreements interact with an array of civil service, merit, and other adjudicative mechanisms. The same issue arises in Canada, and as in the United States, has also received insufficient attention. The final chapter in the volume, by Heather Grob, looks at the construction industry and is fascinating on two accounts. First, there is a long tradition of dispute procedures that go well beyond union-management disputes, such as inter-union jurisdictional tribunals. Second, and most interesting, the construction industry's seemingly arcane rules are not seen as a dinosaur of the past but as a harbinger of the future. The employee side is characterized by a contingent workforce, occupational unions that control entry and training, and industry based (rather than employer based) pensions and benefits. On the employer side, competitive bidding, outsourcing, constantly changing technology, many small employers, and constant entrants to the market were a fact of life well before the high tech sector was invented. Professor Grob makes a persuasive case for looking to the construction industry as a model of future workplace relationships.

In short, this is a book that must be added to the collection of all industrial relations scholars, even those whose main interests lie outside dispute resolution. For Canadian academics, the debate over nonunion arbitration is fascinating and essential reading. Indeed, there is some anecdotal evidence of the importing of such systems into the Canadian operations of American companies.

\section{Allen Ponak University of Calgary}

\section{Values at Work: Employee Participation Meets Market Pressures at Mondragon \\ by George ChEney, Ithaca and London: ILR Press, 1999, 189 p., ISBN 0- 8014-3325-8.}

Mondragon has been widely viewed as a model of workers' participation: a worker owned and democratically run organization which is also highly successful. Founded by a Catholic priest in the Basque country of Spain during the 1940s and 1950s, this closely linked set of producers' cooperatives has grown to include 150 firms, 42,000 employees and over $\$ 7$ billion in sales.

There have been numerous studies seeking to explain Mondragon's success. The present volume asks another question: has this success come at the cost of Mondragon's soul? Has it maintained its social values (democracy, equality, and solidarity) or has it become more concerned with competitiveness, productivity and pleasing the customer? The author, a student of communications, is concerned with how patterns of discourse reveal fundamental aspects of organizational life. His research involved over 300 interviews and over six months of observation spread over a seven-year period, concentrating on three affiliated coops.

Considerable evidence is presented as to how and why Mondragon's values have degenerated. Historically, "solidarity" - communal obligation and a sense of equality - was a fundamental Basque value, and this was reinforced by the geographical isolation of the separate valleys into which the Basque territory is divided. Mondragon was a 